\title{
FEATURE Sedimentation, navigation, and agriculture on the lower Missouri River
}

\author{
Kenneth R. Olson and Lois Wright Morton
}

$\mathrm{T}$ he Missouri River arises from the eastern slope meltwaters of the Rocky Mountains in the northwestern United States. As it flows across the Great Plains to its confluence with the Mississippi River at St. Louis, Missouri, it accumulates a large sediment load earning it the name "Big Muddy."The natural gravity of water is powerful, capable of carving rocks and eroding soils to create new channels and deepen existing ones via the continuous sediment transport and deposition processes. Rates of upland and river bank sediment erosion, deposition, and transport are influenced by upstream geology, topography, vegetation, and land uses; variations in climate and weather; and the river flow structure and channel morphology (Nazari-Giglou et al. 2016; Coleman and Smart 2011). The headwaters of the Missouri River and it major tributaries, the North and South Platte rivers and the Yellowstone (figure 1), are fast moving, and they cut narrow, deep channels as they rush down steep mountain slopes. However, the waters slow as they flow into the Great Plains and spread out into broad, shallow, braided streams that redistribute sands and silts and create sandbars, wetland backwaters, and new pathways (figure 2).

River sedimentation is the result of natural and anthropogenic processes. Human settlements, increased agricultural production, and desire for river navigation have affected river velocities, sedimentation rates and transfer, and investments in managing the Missouri River. Prior to westward settlement and the growth of agriculture in the river valleys and floodplains, the Missouri River is estimated to have carried 159 to 290 million t $\mathrm{y}^{-1}$ (175 to 320 million tn $\mathrm{yr}^{-1}$ ) of sediment to the Gulf of Mexico via the Mississippi River (USACE 2007).

Kenneth R. Olson is professor emeritus of soil science in the College of Agricultural, Consumer, and Environmental Sciences, University of Illinois, Urbana, Illinois. Lois Wright Morton is professor emeritus of sociology, College of Agriculture and Life Sciences, lowa State University, Ames lowa.

\section{Figure 1}

The North Platte, South Platte, and Platte rivers and the Yellowstone River are major tributaries of the Missouri River flowing east out of the Rocky Mountains across the Great Plains. Campsites of the Lewis and Clark 1803 to 1804 expedition up the Missouri River to find the Northwest Passage are noted on the map.

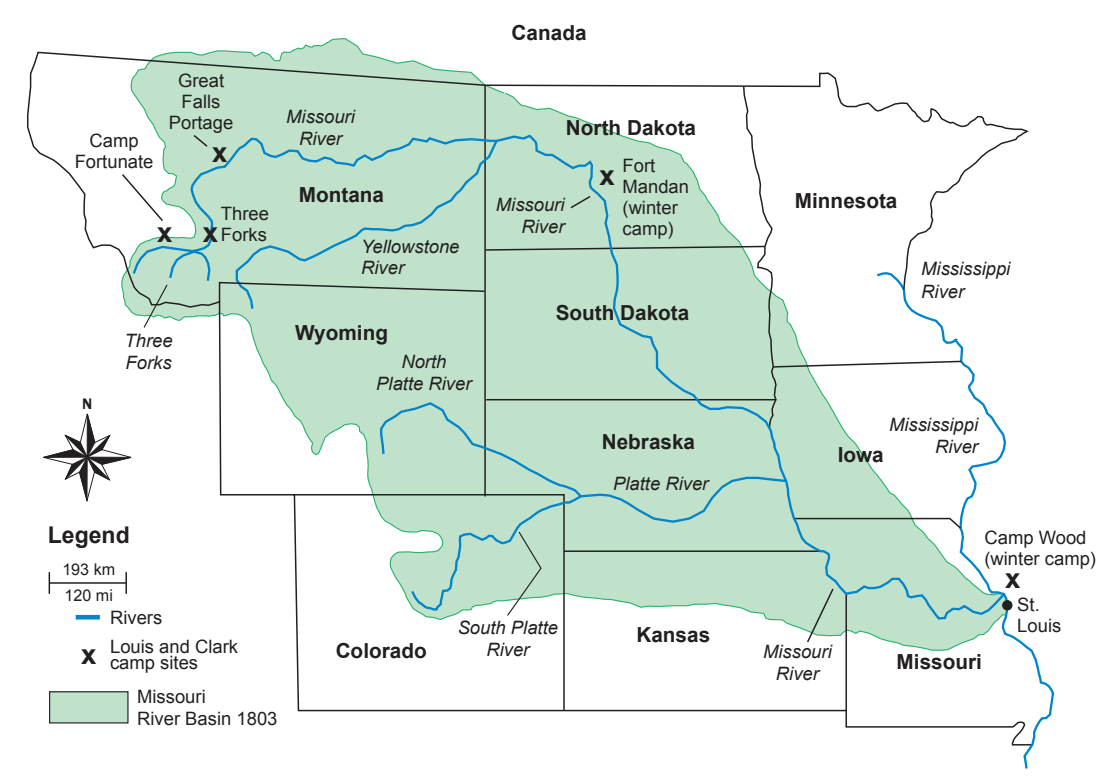

Commercial navigation on the lower Missouri river started in 1819.A $1.5 \mathrm{~m}(6 \mathrm{ft})$ shipping channel was dug and maintained by snag removal and dredging between St. Louis, Missouri, and Sioux City, Iowa. Navigation on the upper Missouri River was restricted by rock falls and later by dams and reservoirs. The building of dams and levees substantially reduced the sediment load the river carries to 18 to 23 million $\mathrm{t} \mathrm{y}^{-1}$ (20 to 25 million tn $\mathrm{yr}^{-1}$ ) (USACE 2007). Reservoirs behind Missouri River dams catch and hold about 33 million $\mathrm{t}^{-1}$ ( 36.4 million $\mathrm{tn} \mathrm{yr}^{-1}$ ) of sediments, thereby preventing them from continuing downstream (USACE 2007). Despite the reduction in downstream sediment transport, the Missouri River basin still contributes the majority of deposits that form the Mississippi River Delta (Schliefstein 2010).

\section{GEOLOGY}

There is geological evidence that the Missouri River watershed prior to the Quaternary Ice Age drained to both the northeast and southeast of modern day Canada and the United States. The upper portion drained north into the Hudson Bay (Moak 2010; Olson and Morton 2016), and the middle and lower portions of the river flowed eastward. The Illinoian glaciation during the Ice Age diverted the Missouri River southeast where it currently joins the Mississippi River above St. Louis, Missouri.

The Platte rivers drain the eastern Rocky Mountains in Colorado and Wyoming and flow across the Great Plains (figure 3) over the Ogallala Formation and older Cenozoic sedimentary rocks. The White River Formation, the lowest major Cenozoic unit, was deposited 35 to 29 million years ago. It is made up of claystone, sandstone, limestone, and conglomerate materials (Love and Christiansen 2011). The Rocky Mountain glaciers scoured the rock material, and when the glaciers melted, the runoff water carried bedrock fragments, gravels, and sands eastward into the Great Plains (Jones 2012). These 
formations, stretching from the Rocky Mountains to eastern Nebraska give the Great Plains an eastward tilt and created a major aquifer that provides water to the Great Plains and western United States today. Weakly cemented sandstone of the Ogallala Group is exposed at the earth's surface north of the Platte River (figure 4). It is a source of the sand that has been deposited by water in rivers and on bottomlands and has been blown into dunes and transported by the Platte River to the Missouri River.

\section{HUMAN IMPACTS ON THE MISSOURI RIVER BASIN}

Humans have occupied the Missouri River watershed (figure 1) for 10,000 to 12,000 years starting at the end of Pleistocene. The first great human in-migration to the Americas began from Asia via the Bering Strait land bridge. The Missouri River and tributaries became one of the major migration paths as people traveled by boat and walked from modern day Alaska southward. Many settled in the Ohio River valley and lower Mississippi River valley as evidenced by archeological findings in these regions. The Mound builders (Middle Mississippi Indians) lived along the Missouri River and became ancestors of the Great Plains indigenous peoples. Native Americans who hunted and settled along the Missouri River had access to abundant food and water. Along with birds and animals native to the region, a large number of migratory animals use the plains as they move seasonally between summer breeding and nesting and wintering grounds. The riparian areas in river floodplains provided Native Americans with herbs, staple foods, and clothing (Public Broadcasting Station 1998). There were 10 major groups of Native Americans who lived in the Missouri River basin and depended on the Great Plains buffalo (Bison bison) herds for food, hides, and bones for clothing and household items. The tribes and peoples of this time could not write, and it was not until European explorers traveled to the Missouri River valley and recorded information about the Native Americans that the major tribes were identified. They included Otoe, Missouria, Omaha, Ponca, Brule, Lakota, Sioux, Arikara, Hidatsa, Mandan, Assiniboine, Gros Ventures, and Blackfoot.

\section{Figure 2}

The Missouri River is a wide, shallow river with sandbars and backwater wetlands as it flows across the Great Plains. This view is from the Nebraska Missouri River overlook on the Nebraska-South Dakota state lines, September of 2016.

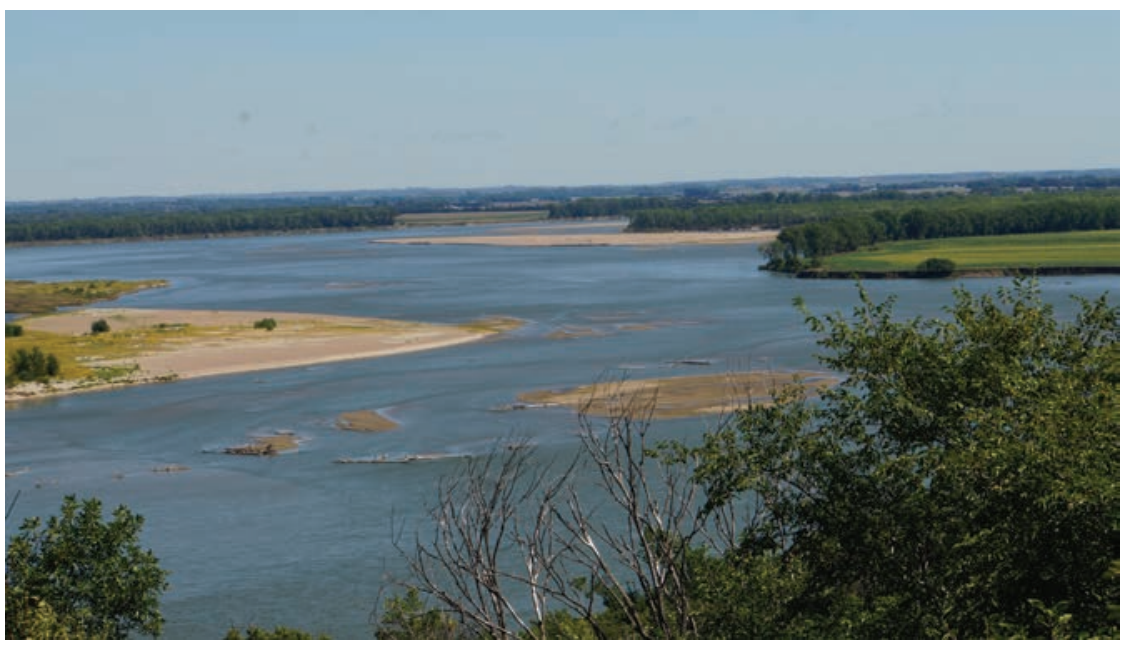

The rivers and tributaries served as tribal boundaries. Later US state boundaries were often rivers, so the practice continued.

Historically, tens of millions of buffalo formed the great bison belt of the Great Plains running along the eastern slopes of the Continental Divide from Alaska through the Missouri River valley grasslands (mostly Mollisols) and extending found the tasty, nutritious regrowth.

\section{EARLY EXPLORERS OF THE MISSOURI RIVER VALLEY}

into Mexico. When indigenous peoples burned the grasslands surrounding the Missouri River, the buffalo herds quickly

Louis Jolliet and Jacques Marquette, French explorers, first documented the

\section{Figure 3}

The North Platte River flows east out of the Wyoming Rocky Mountains, and the South Platte flows northeast from Colorado Rockies to form the Platte River in central Nebraska.

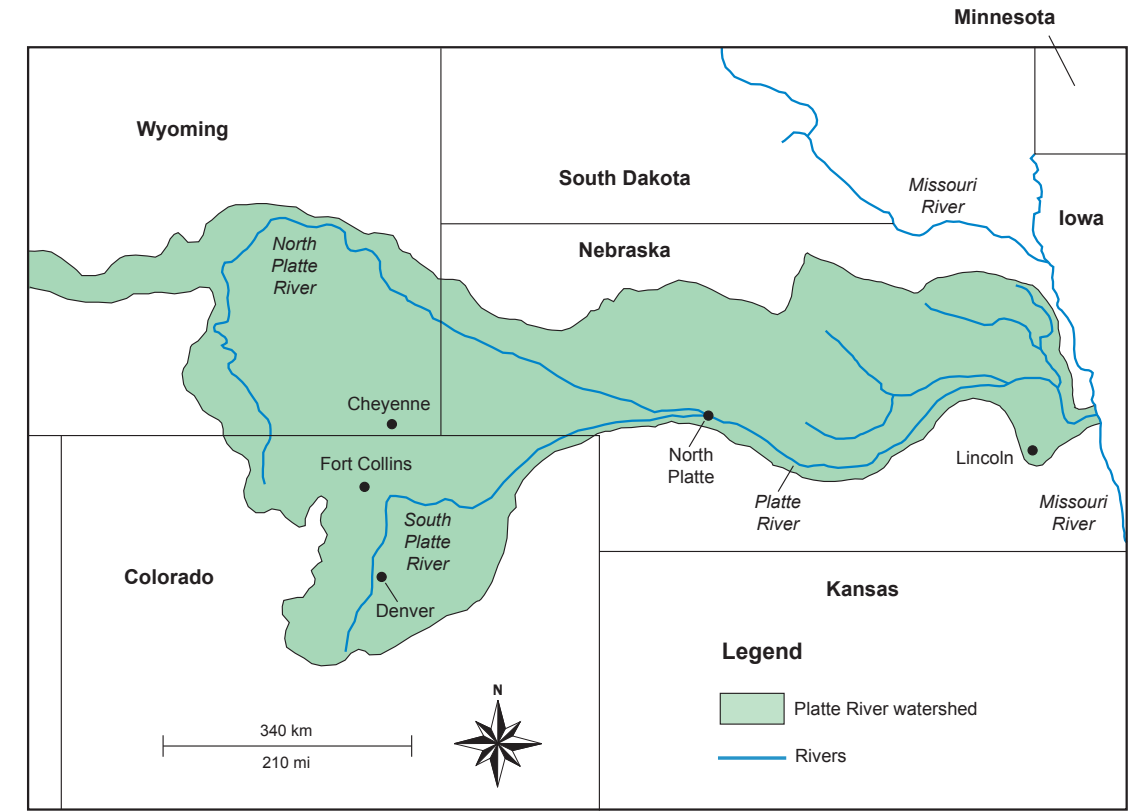




\section{Figure 4}

The Ogallala Formation underlies much of the Great Plain states east of the Rocky Mountains. The northernmost portion of the Ogallala, found primarily in Nebraska, has extensive sand dunes. This area, known as the Sandhills, is a major migratory flyway for Sandhill cranes and other birds between Mexico and Canada.

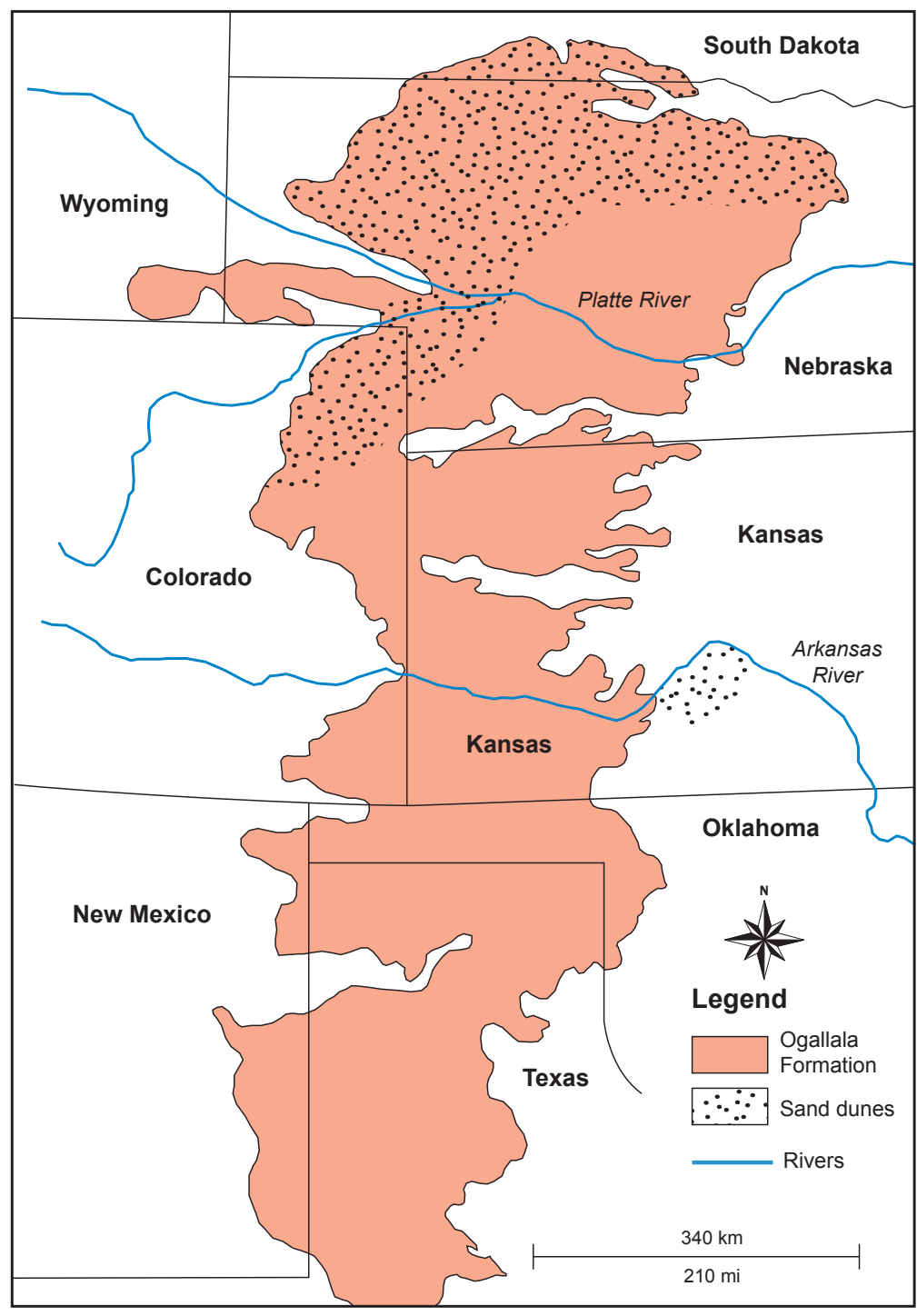

Missouri River confluence with the Mississippi River in May of 1673, but the rivers were flooding at the time so they did not explore upstream (Morris 1991). Soon thereafter, France expanded their claims of territory in North America to lands west of the Mississippi River, including the lower Missouri River. The region was not explored until 1774 when Bourgmont led an expedition that extended west to the mouth of the Platte River. He subsequently published a book, Route to $\mathrm{Be}$ Taken to Ascend the Missouri River, which became the first recorded naming of the Missouri River.
More than 20 years later, Spain and the United States signed Pinckey's Treaty giving the new nation rights to navigate the Mississippi River on its western border (Illinois State Museum 2011). In 1798, Spain revoked the treaty and by 1800 had returned Louisiana to Napoleonic France. Fearing that the United States could be cut off from using the port of New Orleans and the Mississippi River, President Thomas Jefferson proposed buying the Port of New Orleans (Olson and Morton 2016) for US\$10 million. France counteroffered and indicated it was willing to sell all of the Louisiana region, including the Missouri River valley, for US $\$ 15$ million-a price less than US $\$ 0.08$ $\mathrm{ha}^{-1}$ (US $\$ 0.03 \mathrm{ac}^{-1}$ ). The deal was signed in 1803 and became known as the Louisiana Purchase (Ambrose 2005).

\section{NAVIGATION ON THE MISSOURI WATERWAY}

Native Americans used wood-framed canoes and bull boats to travel the Missouri River. The river enabled European exploration and navigation as US westward migration and trade exchanges throughout the Great Plains increased. The Independence was the first steamboat on the Missouri River. It ran between St. Louis and Keyesville, Missouri, starting in 1819; and by the 1830 s, vessels were regularly carrying mail and freight between St. Louis and Kansas City, Missouri. Some boats went upriver as far as eastern Montana (Dyer 1997). Over 130 steamboats operated full time by 1850 . The average steamboat lasted only four years because navigation on the Missouri was dangerous with groundings and wrecks often occurring.

In the early $1900 \mathrm{~s}$, a $1.8 \mathrm{~m}$ (6 ft) channel was authorized by the federal government, and the US Army Corps of Engineers (USACE) maintained the river depth a distance of $592 \mathrm{~km}$ (368 mi) from the Port of St. Louis at the Mississippi River confluence upriver to Kansas City. Hundreds of wing and closing dams were built to increase the river depth. Many are still in use today. Wing dams are wood and stone structures that extend into the channel at a $90^{\circ}$ angle from the river bank. Closing dams block the main channel from diverting water into backwaters and floodplain side channels. Levees and wing dams reduce sedimentation by directing the river's flow, resulting in a straighter and narrow channel that increases the river depth and velocity.

The Missouri River has been extensively engineered and managed for navigation. Almost one-third of its water flows through reengineered and straightened channels. The USACE widened the navigation channel to $61 \mathrm{~m}(200 \mathrm{ft})$ in 1925 and then began dredging and deepening the river from Kansas City, Missouri, to Sioux City, Iowa, thereby reducing the distance between the two ports by $323 \mathrm{~km}$ (199 mi). Construction of six dams on the 
Missouri River main stem in the 1940s and 1950s ensured the $1.8 \mathrm{~m}(6 \mathrm{ft})$ depth and provided year-round navigation. Variations in the climate and seasons, such as the drought of 2012 and historic floods of 1993 and 2008, create high and low water cycles and make it difficult to control the depth and velocity of the Missouri River even with these storage reservoirs.

The USACE Missouri River Bank Stabilization and Navigation Project began in 1945 to permanently increase the river's navigation channel to $91 \mathrm{~m}(300 \mathrm{ft})$ and a depth of 2.7 (9 ft). The 1,183 km (735 mi) navigation channel from Sioux City downstream to St. Louis is maintained through riverbed dredging and rock dikes. This effort is intended to seal and cut off meanders and side channels and direct the river's flow to keep sediments from depositing in the channel (USACE 2007). However, controlling the depth of the Missouri River and preventing silting and sedimentation is a continuous process. Several US Coast Guard boats ran aground in 2006 because the minimum navigation channel depth was reduced by silt and sedimentation.

Communities established at river ports, such as Sioux City, Kansas City, and St. Louis, became important economic, cultural, and social hubs and were instrumental in unifying the United States as a nation (Olson and Morton 2016). The Missouri River Navigation Commission's 1927 estimate of total goods shipped on Missouri River annually was 13.6 million $\mathrm{t}$ ( 15 million $\mathrm{tn})$. This created strong support for deepening and widening navigation channels. However, shipping traffic has declined in recent years with one of the largest decreases occurring in the transport of agricultural products, particularly wheat (Triticum aestivum L.). Missouri River barges moved agricultural raw and finished products, oil, lumber, and manufactured items an annual average of only

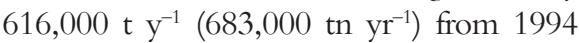
to 2006. There are a number of reasons for the reduced tonnage, including competition from railroads. In addition, vast bottomland areas (more than $800 \mathrm{~km}$ [500 mi]) that were formerly farmed have been covered by reservoirs in South Dakota, North Dakota, and Montana. Irrigated lands along the Missouri River and tributaries have potential to bolster crop production but have not been fully
developed.The wing dams that jetty out into the Missouri River to manage the sediment and river depth can make navigation more difficult for barge traffic. Further, the lower Missouri River does not have locks and dams like the upper Mississippi River. The 29 locks and dams on the upper Mississippi River had an average 68 million $\mathrm{t}(61 \mathrm{mil}-$ lion tn) of cargo annually pass through them from 2008 to 2011 (USGS 2014).

\section{PLATTE RIVER VALLEY LAND USE AND AGRICULTURE}

Insufficient water is a major limitation to agricultural production in the northern Great Plains. The precipitation gradient runs west to east, with much of the western region receiving less than $43 \mathrm{~cm}$ (17 in) average annual precipitation and the eastern averaging $79 \mathrm{~cm}$ (31 in) annually (Shafer et al. 2014). The area is highly susceptible to drought as annual water loss from plant transpiration and evaporation is frequently higher than annual precipitation. This makes the Missouri River and tributaries critical water resources for human, animals, and plants.

The North and South Platte rivers emerge from the Rocky Mountain snowmelt in Colorado and Wyoming and meet near the town of North Platte, Nebraska, to form the Platte River (figure 3). The Platte River, about 500 km (310 mi) long, is a major tributary of the lower Missouri River and has a 77,000 km² $(19,027,000$ ac) basin. The North Platte River watershed encompasses $80,000 \mathrm{~km}^{2} \quad(30,000$ $\mathrm{mi}^{2}$ ), and the South Platte River drainage basin is $73,000 \mathrm{~km}^{2}\left(28,000 \mathrm{mi}^{2}\right)$. Many of the river valleys and bottomlands in this region are used for irrigated agriculture that is made possible by 8 dams on the North Platte River and 20 on the South Platte River. The broad, shallow Platte River is not easily navigated, with its muddy silted bottom and numerous islands. Although it was not a good river to canoe and was never used as a major water route, it was an important land trail for settlers and adventurers traveling west to Oregon, California, Utah, and Montana.

\section{LAKE C.W. MCCONAUGHY HYDRO- IRRIGATION PROJECT}

The $5.6 \mathrm{~km}(3.5 \mathrm{mi})$ Kingsley Dam on the North Platte River created a lake $35 \mathrm{~km}$
(22 mi) long with a maximum width of $6.4 \mathrm{~km} \mathrm{(4} \mathrm{mi).} \mathrm{It} \mathrm{covers} 144 \mathrm{~km}^{2}(35,700$ ac) and has a $122 \mathrm{~km}$ (76 mi) shoreline. The reservoir, Lake McConaughy (dam constructed between 1936 and 1941), was designed to store irrigation water for the Central Nebraska Public Power and the Irrigation District's tri-county hydro-irrigation project (CNPPID 2009) (figure 5). It also was a source of more than 15,000 jobs in the region during the Great Depression when it was constructed. In 1984 a hydroelectric plant was added to provide rural electricity to the region at a cost of US $\$ 43$ million. The dam was uniquely engineered by pumping gravel and sand from the riverbed to form the sides. Concurrently, a mixture of silty soil and water was pumped into the center of the structure to form a watertight core. A wall of interlocked sheet piling driven 10 to $49 \mathrm{~m}$ (30 to $160 \mathrm{ft}$ ) deep is tied into the impervious Brule clay formation that lies beneath the dam and prevents the seepage of water under the dam.

\section{THE SANDHILLS}

The North and South Platte rivers' confluence is located over the northern portion of the Ogallala Formation and intersects the prairie grass-covered Sandhills of central Nebraska and northeastern Colorado (figure 4) (Bleed 1990). These sand dunes occupy more than $25 \%$ of the state of Nebraska and became a national natural landmark in 1984. The area encompasses $50,000 \mathrm{~km}^{2}\left(20,000 \mathrm{mi}^{2}\right)$ to $61,000 \mathrm{~km}^{2}$ $\left(23,600 \mathrm{mi}^{2}\right)$. The Sandhill area is 1,000 $\mathrm{m}(3,300 \mathrm{ft})$ above sea level in the west and drops to $550 \mathrm{~m}(1,800 \mathrm{ft})$ in the east. Individual sand dunes can be as high as $100 \mathrm{~m}$ (330 ft). Tributaries of the Loup, Niovbrara, and North Platte rivers drain the eastern and central portion of the Sandhills. The western portion has a series of shallow lakes and closed drainage basins.

The vegetation in the region is scrub desert, and until the 1870s the Sandhills were considered irreclaimable. This semiarid region receives $58 \mathrm{~cm}$ (23 in) rainfall in the east and $43 \mathrm{~cm}$ (17 in) rainfall in the west. Temperatures range from $-34^{\circ} \mathrm{C}\left(-30^{\circ} \mathrm{F}\right)$ to $41^{\circ} \mathrm{C}\left(105^{\circ} \mathrm{F}\right)$. In the late 1800 s attempts were made to cultivate up to $15 \%$ of the area. The 1862 Homestead Act allowed 


\section{Figure 5}

Kingsley Dam on the North Platte River provides water storage (Lake McConaughy) for irrigation and hydroelectricity.

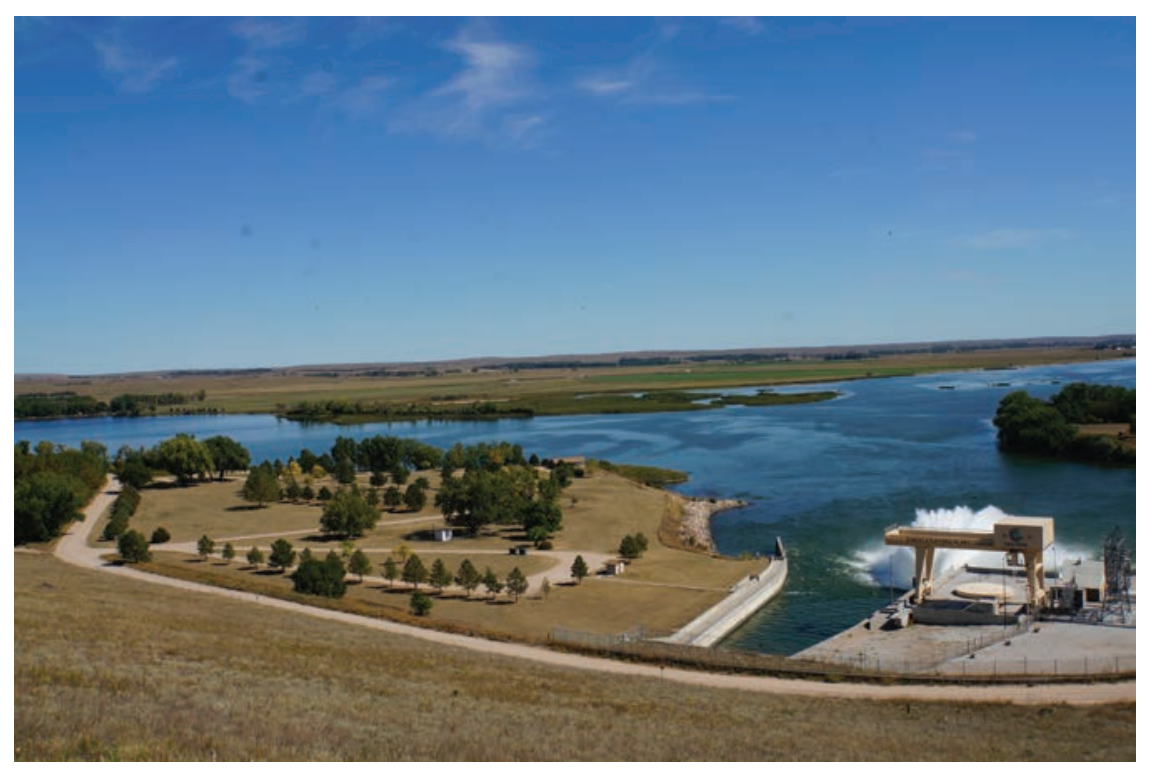

homesteaders to claim $2.6 \mathrm{~km}^{2}$ (640 ac), and nearly $36,000 \mathrm{~km}^{2}$ (9 million ac) were settled between 1910 and 1917. Although the erodibility of the soils made the Sandhills unsuitable for cultivation, cattle producers discovered the Sandhills could be used as rangeland. However, the largest ranches often failed in part due to regulations against fencing of federal lands used for grazing (Nebraska State Historical Society 2007).

Dams on the river enable some of the Sandhills to be cultivated with the use of center-pivot irrigation systems (CNPPID 2009). The US Third National Climate Assessment (Shafer et al. 2014) documents increased vulnerability of this region to changing climatic conditions. They note that warming winters and shifts in the timing and magnitude of rainfall events have been observed over several decades and are affecting agriculture and livestock management. Prairie grasslands receiving low precipitation are more unstable and highly susceptible to wind erosion, drought, and fires (Mangan et al. 2004)

\section{RECREATION ON THE MISSOURI RIVER}

One of the most dramatic natural events along the Platte River is the spring migration and mating season of the Sandhill cranes (Grus Canadensis) and their fall migration south to warmer weather.
Visitors come from around the world to witness the annual spring event as hundreds of thousands of cranes feed in the Nebraska cornfields (Zea mays L.) and roost in the Platte River mudflats for several weeks building up reserves for their trip north into Canada, Alaska, and Siberia to nest. A partnership among several private and public agencies is investing considerable effort to preserve the Sandhills (e.g., US Fish and Wildlife Service, West Central Research and Extension Station, Institute of Agriculture and Natural Resources, The Nature Conservancy of Nebraska, Natural Resource Conservation Service, Nebraska Natural Heritage Program, and University of Nebraska).

The Missouri River basin supports over 300 species of birds and 150 species of fish and an abundance of mammals such as mink (Neovison vison), muskrats (Ondatra zibenthicus), beavers (Castor canadensis), and river otters (Lontra canadensis). There are many marinas and recreational areas, public and private, that are great places for camping, day picnics, swimming, and boating. Wildlife-oriented recreation includes yearround fishing, waterfowl hunting, island camping, water sports, and bird watching, plus opportunities to observe nesting and hatching areas for waterfowl and breeding grounds for aquatic furbearing mammals.
Several of the conservation areas along the Missouri River are Valentone National Wildlife Refuge (77 $\mathrm{km}^{2}$ [19,000 ac]), Crescent Lake National Wildlife Refuge $\left(175 \mathrm{~km}^{2}\right.$ [46,000 ac]), and The Nature Conservancy's Niobrara Valley Preserve $\left(202 \mathrm{~km}^{2}[60,000 \mathrm{ac}]\right)$.

\section{KEYSTONE PIPELINE}

The Missouri River basin lies between between Hardisty, Alberta, Canada, oil sand production and two TransCanada Keystone pipeline terminals in the United States, one in Illinois and the other in Texas (figure 6). Commissioned in 2010, the first three phases are currently in operation. The fourth phase, Keystone XL, has resulted in environmental protests and become part of a larger social debate over the environment, greenhouse gas emissions, fossil fuels, and atmospheric effects to the global climate. Concerns about Keystone pipeline routes that ran through central Nebraska resulted in the Nebraska legislature convening a special session. Key issues included the high concentration of wetlands, sensitive ecosystems, extensive areas of very shallow groundwater, and the unique Sandhill habitat and migratory flyover. As a result, an alternative route was proposed to the east of the Ogallala Formation and sand dunes. However, after a six-year federal review, the fourth phase of the pipeline project was rejected by the US State Department as part of the Presidential Permit Review Process Project. More recently, in January of 2017, the President Trump administration asked the TransCanada Keystone XL group to resubmit their proposal and issued a presidential memorandum to expedite the environmental review process (Mufson 2017).

\section{IMPACT OF FLOOD OF 2011 ON THE LOWER MISSOURI RIVER VALLEY}

The dams and reservoirs on the upper Missouri River manage spring meltwater and store water to maintain river navigation depths on the lower Missouri River. Iowa, Nebraska, and Missouri levees that protect agricultural lands and communities also depend on these reservoirs to prevent levee failure and manage the river 


\section{Figure 6}

The Keystone route from Hardisty, Alberta, Canada, to Patoka, Illinois, and Port Arthur, Louisiana, was moved east to protect the Ogallala Aquifier, the Sandhills, and other unique, environmentally sensitive ecosystems.

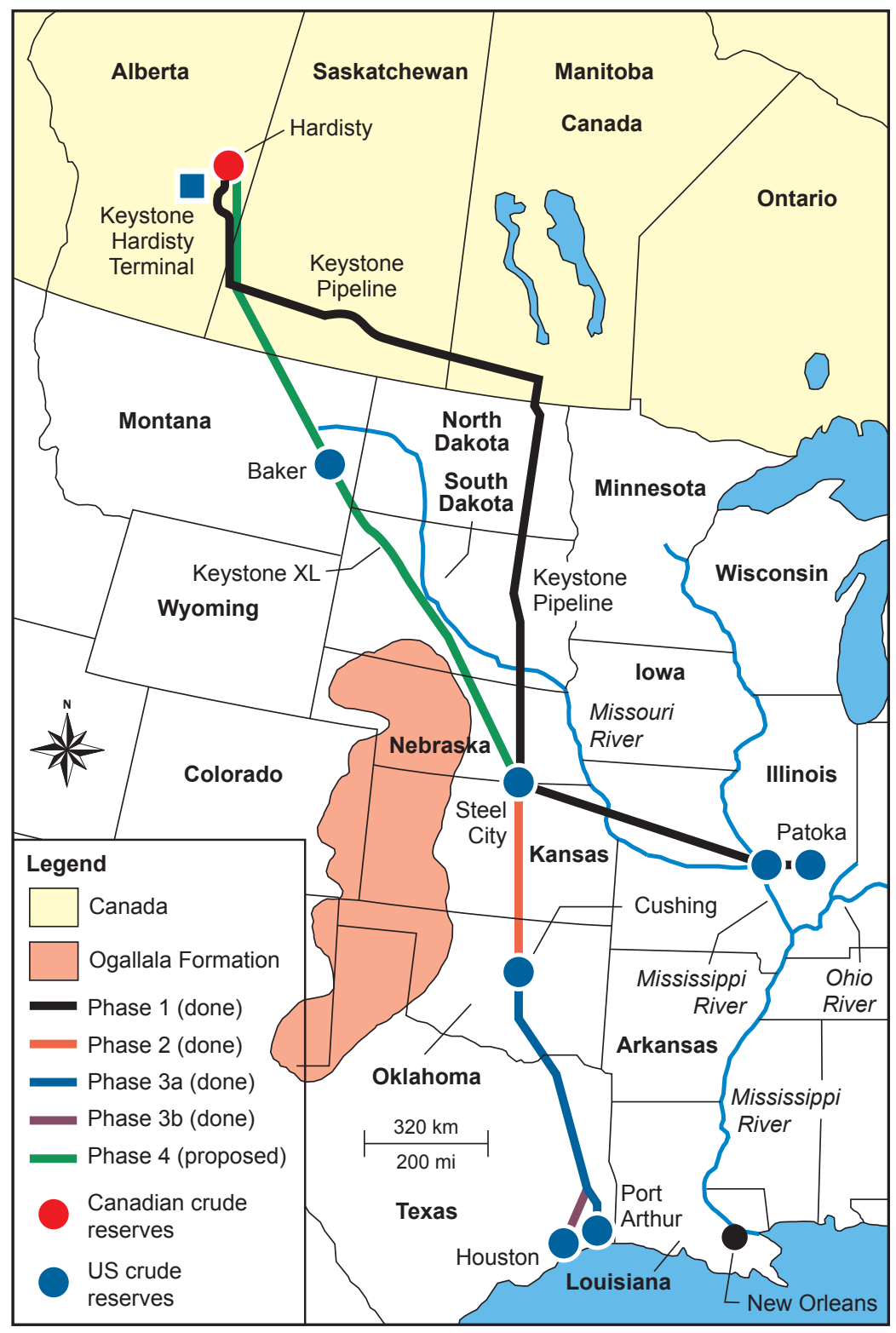

during peak flow periods of high precipitation and fast runoff.

The 2011 spring flood closed several Missouri River bridges north of Gavins Point, South Dakota, all the way south to northern Missouri. River crossings were impossible for over $160 \mathrm{~km}$ (100 mi) from Sioux City, Iowa, to Omaha, Nebraska; and $160 \mathrm{~km}$ (100 mi) from Plattsmouth, Nebraska (just south of Omaha), at mile marker 591 to St. Joseph, Missouri, at mile marker 450. From June 4 to June 13, the levee near Hamburg, Iowa (mile marker 575), was under flood water pressure and finally collapsed on June 13. The USACE raised the levee surrounding Hamburg, Iowa, $3 \mathrm{~m}(10 \mathrm{ft})$ to protect the town.

The Fort Calhoun Nuclear Generating Station reactor plant grounds south of Omaha were inundated by floodwaters (Lincoln Journal Star 2011). The complex's elevator is $306 \mathrm{~m}(1,014 \mathrm{ft})$ above sea level, and by June 19 the river was within 0.5 to $1.8 \mathrm{~m}(1.6$ to $6 \mathrm{ft})$ at 306.5 m (1,006 ft). Plant operators projected that the Calhoun plant could handle up to $308 \mathrm{~m}(1,014 \mathrm{ft})$ because a $2.4 \mathrm{~m}$ (8 $\mathrm{ft}$ ) high rubber berm surrounded the reactor. However, this high rubber berm with a length of $610 \mathrm{~m}(2,000 \mathrm{ft})$ collapsed on June 26, 2011, after being punctured by a small earthmover (Wald 2011). Water flooding Iowa cropland at a bend in the river opposite the Fort Calhoun Nuclear Generating Station Reactor led the local levee authority to blow up their Iowa levee 10 river miles south of the reactor at mile marker 637 on July 1 to reduce river pressure on other portions of the levee.

\section{SUMMARY AND RECOMMENDATIONS}

Flowing water produces, deposits, and transfers sediments from one location to another. The Missouri River and its tributaries are dynamic and continually changing, moving coarse stones, gravels, sands, and silts. Its power caves in streambanks and erodes river islands, and redeposits them further downstream. When the river overflows its banks, it carries the soils from the floodplain and eroded upland agricultural soils downstream creating sand dunes, mud flats, and deltas. Humans have accelerated the natural sedimentation process through land uses, agricultural policies and decisions, and river management.

Dams on Missouri River tributaries have changed rural livelihoods and the economics of the basin by reducing downstream flooding, generating hydroelectric power, and irrigating agricultural crops. Historically, thousands of square kilometers (thousands of square miles) of river floodplains supported a diverse and abundant variety of animal and plant species. More than one-third of the river floodplains are now leveed and support agriculture. Wing dams, closing dams, and dredging deepened the channel of the lower Missouri River and improved navigation from the Mississippi River confluence at St. Louis upstream to Kansas City, Missouri, and Sioux City, Iowa.These river structures and levees have increased the stream velocity that keeps sediments suspended but also during flooding increase peak flows in downstream areas. Elevated levels of nitrogen $(\mathrm{N})$ and other 
nutrients from agricultural fertilizers have changed the water quality of the Missouri River contributing the Gulf of Mexico hypoxia via the Mississippi River. Soil erosion from cultivated systems carries away valuable nutrients needed for crop growth and adds to river sedimentation that clogs navigation channels and river ports. Balancing economic and environmental aspects of the river is a challenge continuing into the future.

The building of six dams between the 1940s and 1960s on the main stem of the Missouri River was insufficient to control flooding in 2011 and permit navigation during the dry season in 2012 on the lower Missouri River. There is a need for the Mississippi River Commission and the USACE to develop a Missouri River and upper Mississippi River plan similar to their lower Mississippi River and tributary plan to address both the upper Mississippi and Missouri river flooding and navigation issues. Such a plan is possible if the northern states adjacent to the Missouri and Mississippi rivers are willing to contribute and participate in the development of the management plan. This plan is essential to address the current waterway infrastructure restoration issues.

\section{ACKNOWLEDGEMENTS}

Partial support for this research was provided by the Iowa Agriculture and Home Economics Experiment Station, College of Agriculture and Life Sciences at Iowa State University and in cooperation with North-Central Regional Project No.1190, Catalysts for Water Resource Protection and Restoration: Applied Social Science Research. Published with funding support from the Director of the Illinois Office of Research, College of Agriculture, Consumer, and Environmental Sciences, University of Illinois, Urbana, Illinois.

\section{REFERENCES}

Ambrose, S.E. 2005. Undaunted Courage. New York, NY: Simon and Schuster.

Bleed, A. 1990. An Atlas of the Sandhills. New York: Conservation and Survey Division of Nebraska at Lincoln, ISBN 1-56161-002-X.

CNPPID (Central Nebraska Public Power and Irrigation District). 2009. A brief history of the central Nebraska Public Power and Irrigation District. http://www.cnppid.com/wp-content/ uploads/2013/11/1history_of_central.pdf.
Coleman, S.E., and G.M. Smart. 2011. Fluvial sediment-transport processes and morphology. Journal of Hydrology 50(1):37-58.

Dyer, R.L. 1997.A brief history of steam boating on the Missouri River. Boone's Lick Heritage, Boonslick Historical Society's Quarterly Magazine 5(2).

Illinois State Museum. 2011. The Mackay and Evans Map. Lewis and Clark in the Illinois Country. Springfield, IL: Illinois State Museum. http://www.museum.state.il.us/exhibits/ lewis_clark_il/htmls/il_country_exp/preps/ mackay_evans_map.html.

Jones, C.H. 2012. Photo map of the western United States: Cenozoic. Western US Tectonics. Boulder, Colorado: University of Colorado.

Lincoln Journal Star. 2011. Low-level emergency declared at nuclear power plant. June 6, 2011. http://journalstar.com/news/ state-and-regional/nebraska/low-level-emergency-declared-at-nuclear-power-plant/ article_d2b85355-0bc8-5733-b3ad6997395d23a6.html.

Love, J.D., and A.C. Christiansen. 2011. White River Formation. Mineral Resources. On-Line Spatial Data. Reston,VA: US Geological Survey. https:// mrdata.usgs.gov/geology/state/sgmc-unit. php?unit=WYTwr\%3B0.

Mangan, J.M, T.T. Overpeck, R.S. Webb, C. Ussman, and A. Goetz. 2004. Response of Nebraska Sandhills natural vegetation as simulated by the CENTURY model to drought, fire, grazing and plant function shifts. Climatic Change 63(1-2):49-90

Moak, W. 2010. Pleistocene Glaciation and Diversion of the Missouri River in Northern Montana. Omaha, NE: University of Nebraska, Department of Geography and Geology. http:// maps.unomaha.edu/maher/2003MBfieldtrip/ Moakreport/Pleistgeo.html.

Morris, A. 1991. Colonial Arkansas, 1686-1804: A Social and Cultural History. Fayetteville: University of Arkansas Press.

Mufson, S. 2017. Trump seeks to revive Dakota Access Keystone XL oil pipeline. Washington Post, January 24, 2017.

Nazari-Giglou, A., A. Jabbari-Sahebari, A. Shakibaeinia, and S.M. Borghei. 2016. An experimental study of sediment transport in channel confluences. International Journal of Sediment Research 31:87-96.

Nebraska State Historical Society. 2007. US Government Land Laws in Nebraska, 1854-1904. Lincoln, NE: Nebraska State Historical Society. http://www.nebraskahistory.org/lib-arch/services/refrence/la_pubs/landlaw7.htm.
Olson, K.R., and L.W. Morton. 2016. Managing Mississippi and Ohio River Landscapes. Ankeny, IA: Soil and Water Conservation Society.

Public Broadcasting Station. 1998. American Buffalo: Spirit of a Nation: A symbol of Strength. November 10, 1998. http://www.pbs.org/wnet/ nature/american-buffalo-spirit-of-a-nationintroduction/2183/.

Schliefstein, M. 2010. Missouri River helped build Louisiana coast, but it won't help restore it. New Orleans Times-Picayune. September 29, 2010. http://www. nola.com/politics/index.ssf/2010/09/ missouri_river_helped_build_lo.html.

Shafer, M., D. Ojima, J.M. Antle, D. Kluck, R.A. McPherson, S. Petersen, B. Scanlon, and K. Sherman. 2014. Chapter 19: Great Plains. In Climate Change Impacts in the United States: The Third National Climate Assessment, eds. J.M. Melillo, Terese (T.C.) Richmond, and G.W. Yohe, US Global Change Research Program, 441-461, doi:10.7930/J0D798BC. http:// nca2014.globalchange.gov/report/regions/ great-plains\#intro-section-2.

USACE (United States Army Corps of Engineers). 2007. Missouri River Sediment. Missouri River Recovery Program. Fact Sheet. Kansas City, MO: USACE Kansas City District. http://www. mostreamteam.org/Documents/Research/ BigRiver/MissouriRiverSediment.pdf.

USGS (United States Geological Survey). 2014. About the Upper Mississippi River System. La Crosse, WI: Upper Midwest Environmental Sciences Center.

Wald, M.L. 2011. Nebraska nuclear plant's vital equipment remains dry. The New York Times, June 27, 2011. 